\title{
Árangur míturlokuskipta á Íslandi
}

\author{
Sigurður Ragnarsson ${ }^{1}$ læknir, Martin Ingi Sigurðsson ${ }^{1}$ læknir, Ragnar Danielsen²,3 |æknir, Pórarinn Arnórsson ${ }^{1}$ læknir, Tómas Guðbjartsson ${ }^{1,3}$ \\ læknir
}

\section{ÁGRIP}

Inngangur: Míturlokuskipti eru næstalgengasta lokuskiptaaðgerð hér á landi á eftir ósæðarlokuskiptum. Tilgangur rannsóknarinnar var að kanna skammtíma- og langtímaárangur míturlokuskipta á Íslandi en pað hefur ekki verið gert áður.

Efniviður og aðferðir: Afturskyggn rannsókn á peim 64 sjúklingum (meðalaldur 59 ár, 63\% karlar) sem gengust undir 66 míturlokuskipti á Landspítala frá 1990 til 2010. Klínískar upplýsingar fengust úr sjúkraskrám og var heildarlifun reiknuð út. Međaleftirfylgd var 7,4 ár.

Niðurstöður: Algengasta ábending aðgerðar var lokuleki hjá 47 sjúklingum (71\%) en 18 (27\%) höfðu lokuprengsli. Fjórðungur hafði áður gengist undir opna hjartaaðgerð, 9 höfðu virka hjartapelsbólgu og 8 nýlegt hjartadrep. Meðal logEuroSCORE var 14,9\% (bil 1,5-88,4) og $83 \%$ sjúklinganna voru í NYHA-flokki III/IV fyrir aðgerð. Sex sjúklingar fengu lífræna loku en hinir gerviloku. Önnur hjartaaðgerð var gerð samtímis hjá tveimur priðju sjúklinga, oftast kransæðahjáveita (41\%) og/eða ósæðarlokuskipti (20\%). Hjartadrep í tengslum við aðgerð (26\%), öndunarbilun (17\%), enduraðgerð vegna blæðingar (15\%) og nýrnabilun sem krafðist skilunar (9\%) voru algengustu alvarlegu fylgikvillarnir. Að auki purfti ECMO-dælu í premur tilfellum vegna hjartabilunar og ósæðardælu hjá 6 sjúklingum. Minniháttar fylgikvillar greindust i $61 \%$ tilfella, oftast fleiðruvökvi sem parfnaðist aftöppunar, nýtilkomið gáttatif og lungnabólga. Sex sjúklingar létust innan 30 daga frá aðgerð (9\%) og 5 ára lífshorfur voru $69 \%$.

Ályktun: Tíðni fylgikvilla var há eftir míturlokuskipti, enda flestir sjúklinganna með alvarlegan undirliggjandi hjartasjúkdóm. Skurðdauði var lægri hér á landi en í mörgum sambærilegum erlendum rannsóknum.
${ }^{1} H$ jarta- og lungnaskurðdeild, ${ }^{2}$ hjartadeild Landspítala, अæknadeild Háskóla Íslands.

Greinin barst: 5. nóvember 2011 sampykkt til birtingar: 8. mars 2012

\section{Inngangur}

Míturlokuskipti eru gerð hjá sjúklingum með prengsli eða leka í lokunni en án meðferðar getur hvort tveggja leitt til alvarlegrar hjartabilunar.1, 2 Gigtsótt (febris rheumatica) er langalgengasta ástæða míturlokuprengsla en sjúkdómurinn leiðir til skemmda á lokublöðum sem prengja lokuopið. ${ }^{1}$ Í próunarlöndum er gigtsótt enn landlæg og míturlokuprengsli pví algeng. ${ }^{3}$ Hér á landi er gigtsótt hins vegar sjaldgæfur sjúkdómur en á Vesturlöndum greinast ný tilfelli míturlokuprengsla aðallega í innflytjendum. ${ }^{3}$ Mikið kalk í míturlokuhring eða lokublöðum getur einnig prengt lokuna, sem og sjaldgæfari orsakir á borð við slímvefjaræxli (cardiac myxoma) í hjartanu. ${ }^{4}$ Við alvarleg míturlokuprengsli hjá fullorðnum (lokuflatarmál undir $1 \mathrm{~cm}^{2}$ ) parf í flestum tilvikum að skipta út lokunni. Við vægum prengslum, sérstaklega hjá börnum, getur komið til greina að losa um lokublöðin með skurðaðgerð (commissurotomy) eða víkka lokuopið með belg, en langtímaárangur er lakari samanborið við míturlokuskipti. ${ }^{1}$ Belgvíkkun er oft reynd í fyrstu en ókostur er að eftir víkkunina verður oft leki í lokunni. ${ }^{5}$

Fjölmargir sjúkdómar geta valdið míturlokuleka. Algengastir eru hrörnunarsjúkdómar í lokunni (degenerative mitral disease), blóðpurrð og hjartapelsbólga. Dæmi um hrörnunarsjúkdóma eru míturlokubakfall (mitral valve prolapse) og slit á stögum lokublaðanna (chordae tendinae). ${ }^{6}$ Bráð blóðpurrð getur valdið drepi í totuvöðva (papillary muscle) sem tengist míturlokunni með tilheyrandi leka í lokunni. Langvarandi blóðpurrð í hjartavöðvanum getur aftur á móti breytt lögun og stærð vinstri slegils, og par með breytt afstöðu totuvöðvanna og lokublaðanna sem getur leitt til míturlokuleka. ${ }^{2}$
Eina vel rannsakaða meðferðin við alvarlegum míturlokuleka er skurðaðgerð, ${ }^{2}$ annaðhvort viðgerð á lokunni eða lokuskipti, en nýrri meðferðir sem byggja á hjartapræðingartækni eru í örri próun.7 Við mat á pví hvort og hvenær beita eigi skurðaðgerð er tekið tillit til klínískra einkenna og niðurstöðu hjartaómskoðunar, sérstaklega mats á stærð og útstreymisbroti vinstri slegils. ${ }^{2}$ Oftast er mælt með aðgerð hjá sjúklingum sem hafa mikinn leka samkvæmt hjartaómskoðun og annaðhvort einkenni hjartabilunar eða skerta samdráttargetu vinstri slegils. ${ }^{8}$ Yfirleitt er reynt að gera við lokublöðin, einkum pegar um hrörnunarsjúkdóm er að ræða, enda talinn besti meðferðarkosturinn. ${ }^{2,} 9$ Ekki er pó alltaf hægt að gera við lokuna, eins og pegar lokublöðin eru skemmd eða pegar leki stafar af bráðu hjartadrepi, og pví gripið til pess að skipta út lokunni. ${ }^{9}$

Míturlokuskipti eru framkvæmd með opinni skurðaðgerð með aðstoð hjarta- og lungnavélar. Míturlokublöðin eru fjarlægð en reynt að halda eftir hluta aftara blaðsins par sem lokustögin festast til að varðveita starfsemi vinstri slegils. ${ }^{10}$ Ýmist er notast við gervilokur (mechanical prosthesis) úr hertu kolefni eða lífrænar lokur (bioprosthesis) sem búnar eru til úr svínalokum eða gollurshúsi kálfa. Sjúklingar með lífrænar lokur purfa ekki langtíma blóðpynningarmeðferð en sjúklingar með gervilokur purfa blóðpynningu ævilangt með warfaríni til að koma í veg fyrir segamyndun. ${ }^{11}$ Meðalendingartími lífrænna loka er talinn vera í kringum 15 ár og pær eru pví jafnan notaðar í eldri sjúklingum. ${ }^{12}$

Fyrstu míturlokuskiptin á Íslandi voru framkvæmd árið 1990 og eru pau næstalgengasta lokuskiptaaðgerðin á eftir ósæðarlokuskiptum. Árangur míturlokuskipta 


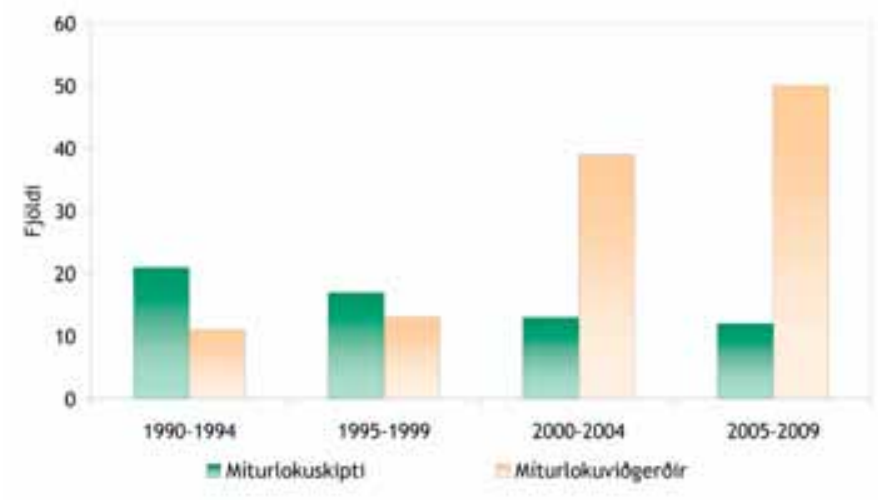

Mynd 1. Fjöldi míturlokuskipta ( $n=66)$ og míturlokuviðgerða $(n=113)$ skipt í fimm ára tímabil.

á Íslandi hefur ekki verið birtur áður og var markmið pessarar rannsóknar að bæta úr pví. Lögð var sérstök áhersla á snemmkomna fylgikvilla, dánartíðni innan 30 daga frá aðgerð og langtímalifun sjúklinganna.

\section{Efniviður og aðferðir}

\section{Sjúklingar og skráðar breytur}

Rannsóknin var afturskyggn og náði til allra sjúklinga sem gengust undir míturlokuskipti á Íslandi á tímabilinu 1. janúar 1990 til 31. desember 2009. Listi yfir sjúklinga fékkst úr gagnagrunni hjarta- og lungnaskurðdeildar Landspítala og sjúklingabókhaldi Landspítala par sem leitað var undir aðgerðarkóða. Úr sömu gagnagrunnum fengust upplýsingar um fjölda sjúklinga sem gengust undir míturlokuviðgerð (mitral valve repair) á rannsóknartímabilinu. Frekari upplýsingar um sjúklinga sem gengust undir míturlokuskipti fengust úr sjúkraskrám. Skráðar voru 139 breytur, meðal annars lýðfræðilegir pættir eins og aldur og kyn, fyrra heilsufar, áhættupættir hjarta- og æðasjúkdóma, saga um hjartabilun, langvinna lungnateppu, nýrnabilun og fyrri hjartaaðgerðir.

Hjartabilunareinkenni sjúklinga voru skráð samkvæmt NYHA-flokkuninni (New York Heart Association) en sjúklingarnir voru einnig metnir með tilliti til áhættu við svæfingu samkvæmt ASA-flokkunarkerfinu (American Association of Anesthesiology). Ábending míturlokuskipta var metin, til dæmis hvort um marktæk prengsli eða leka var að ræða og hugsanleg ástæða lekans, svo sem míturlokubakfall, hjartapelsbólga eða hjartadrep. Нæð og pyngd voru skráð samkvæmt svæfingarblöðum og út frá peim upplýsingum reiknaður líkamspyngdarstuðull. Einnig var reiknað út logistic EuroSCORE (European System for Cardiac Risk Evaluation) afturvirkt fyrir alla sjúklinga en pað er áhættulíkan sem metur líkur á andláti innan 30 daga frá opinni hjartaaðgerð.

\section{Hjartaómskoðun og kransæðapræðing}

Orsök míturlokusjúkdóms var metin með hjartaómun frá brjóstvegg en einnig var gerð vélindaómun hjá hluta sjúklinga. Skráðar voru mælingar afturvirkt úr fyrirliggjandi hjartaómskoðun, meðal annars stærð vinstri slegils, útstreymisbrot (ejection fraction) og stærð vinstri gáttar. Hjá sjúklingum með prengsli var mælt meðalprýstingsfall yfir lokuna og flatarmál prengsla reiknað með prýstingshelmingunartíma-aðferð. ${ }^{13}$ Einnig var metinn leki í lokunni á skalanum frá einum (vægur leki) og upp í prjá (mikill leki) með Doppler-aðferðum. ${ }^{14}$ Útbreiðsla kransæðasjúkdóms var skráð samkvæmt niðurstöðum fyrirliggjandi hjartapræðingar.
Tafla I. Sjúklingatengdir pættir, fjöldi sjúklinga (\%), meðaltöl með staðalfrávikum fyrir aldur og EuroSCORE.

\begin{tabular}{|c|c|}
\hline Karlar & $40(63)$ \\
\hline Aldur (ár) & $59 \pm 14$ \\
\hline Háprýstingur & $13(20)$ \\
\hline Sykursýki & $2(3)$ \\
\hline Saga um reykingar & $41(62)$ \\
\hline Líkamspyngdarstuðull $\geq 25$ kg/m2 & $32(49)$ \\
\hline Langvinn lungnateppa & $7(11)$ \\
\hline Nýrnabilun (kreatínín >200 ㅆmol/L fyrir aðgerð) & $7(11)$ \\
\hline Virk hjartapelsbólga & $10(15)$ \\
\hline Kransæðasjúkdómur & $40(56)$ \\
\hline Lungnaháprýstingur, slagbilsprýstingur $>60$ mmHg & $18(27)$ \\
\hline Saga um fyrri hjartaaðgerð & $16(24)$ \\
\hline \multicolumn{2}{|l|}{ NYHA-flokkur } \\
\hline $1+I I$ & $9(14)$ \\
\hline III + IV & $57(87)$ \\
\hline \multicolumn{2}{|l|}{ ASA-flokkur* } \\
\hline $\mathrm{I}+\mathrm{II}$ & 0 \\
\hline III & $41(62)$ \\
\hline IV & $25(38)$ \\
\hline EuroSCORE (log) & $14,9 \pm 20,0$ \\
\hline
\end{tabular}

${ }^{*}$ American Association of Anesthesiology

Gerð og tegund loku var skráð, hvort aðrar hjartaaðgerðir voru gerðar samtímis lokuskiptunum, auk fjölda kransæðatenginga ef gerð var kransæðahjáveituaðgerð. Sömuleiðis var skráður heildaraðgerðartími, tími á hjarta- og lungnavél og tangartími (aortic cross-clamp time). Blæðing fyrstu 24 klukkustundir eftir aðgerð var skráð í millilítrum og tími í öndunarvél í klukkustundum. Einnig var skráður fjöldi eininga sem gefnar voru af rauðkornapykkni, blóðflögum og blóðvökva.

Skilgreiningar á fylgikvillum og skurðdauða

Fylgikvillar sem greindust innan 30 daga frá aðgerð voru taldir til snemmkominna fylgikvilla og skiptust peir í alvarlega og minniháttar fylgikvilla. Alvarlegir fylgikvillar voru skilgreindir sem enduraðgerð vegna blæðingar, aðrar enduraðgerðir, djúp sýking í bringubeinsskurði, bráður nýrnaskaði sem parfnaðist blóðskilunar, öndunarbilun sem krafðist öndunarvélar í meira en eina viku, drep í heila og hjartadrep. Hjartadrep var skilgreint sem nýjar SThækkanir eða Q-takkar á hjartariti eða CK-MB mæling yfir 100 $\mu \mathrm{g} / \mathrm{L}$ eftir aðgerð hjá sjúklingi sem ekki hafði hjartadrep fyrir aðgerð. Til minniháttar fylgikvilla töldust gáttatif, pvagfærasýking, lungnabólga, nýrnaskaði sem ekki krafðist skilunar, fleiðru- eða gollurshúsvökvi sem krafðist tæmingar og minniháttar hjartaskaði. Minniháttar hjartaskaði var skilgreindur sem hæsta CK-MB gildi á bilinu 70-100 g/L. Nýrnaskaði sem ekki krafðist skilunar var skilgreindur sem kreatínín $>200 \mu$ mol/L hjá sjúklingum sem ekki höfðu hækkað kreatínín fyrir aðgerð. Skurðdauði (operative mortality) var skilgreindur sem andlát innan 30 daga frá aðgerð. Legutími á gjörgæslu var reiknaður í klukkustundum og heildarlegutími í heilum dögum. 
Tafla II. Ástæður míturlokuleka. Fjöldi (\%).

\begin{tabular}{lc}
\hline Bakfall á míturlokublaði/blöðum & $17(36)$ \\
\hline Slit á sinastrengjum míturloku & $4(9)$ \\
\hline Hjartapelsbólga & $9(19)$ \\
\hline Langvarandi blóðpurrð í slegli & $4(9)$ \\
\hline Bráð blóðpurrð (rof á totuvöðva) & $2(4)$ \\
\hline $\begin{array}{l}\text { Lokuleki vegna endurleka eftir fyrri míturlokuviðgerð } \\
\text { (enduraðgerð) }\end{array}$ & $5(11)$ \\
\hline $\begin{array}{l}\text { Enduraðgerð eftir fyrri lokuskipti (hliðarleki, segi, } \\
\text { hjartapelsbólga) }\end{array}$ & $4(9)$ \\
\hline Míturlokukölkun & $2(4)$ \\
\hline
\end{tabular}

\section{Tölfræðð og leyfi}

Breytur voru skráðar í forritið Excel og SPSS útgáfu 16.0 og pað notað við lýsandi tölfræði og einbreytugreiningu. Aðrir tölfræðiútreikningar voru gerðir í $\mathrm{R}$, útgáfu 2.5.10 ( $\mathrm{R}$ foundation for Statistical Computing, Vín, Austurríki) og miðast marktæki við p gildi $<0,05$. Aðferð Kaplan-Meier var notuð til að áætla heildarlifun (overall survival) og var dánardagur skráður samkvæmt upplýsingum frá Hagstofu. Forspárpættir lifunar voru metnir með fjölbreytugreiningu Cox (Cox proportional hazard ratio) og eru gefnir upp sem áhættuhlutfall (ÁH, hazard ratio) með 95\% öryggisbilum (ÖB, confidence interval). Líkanið innihélt eftirfarandi breytur; aldur, kyn, EuroSCORE, NYHA-flokk, ábendingu fyrir aðgerð (leki eða prengsli), tangartíma og hvort önnur aðgerð var framkvæmd samtímis. Allar breytur líkansins stóðust kröfur um hlutfallsbil (proportionality), svo skilyrði Cox-líkansins töldust uppfyllt.

Rannsóknin var framkvæmd með tilskildum leyfum frá Persónuvernd og Vísindasiðanefnd og framkvæmdastjóra lækninga á Landspítala.

\section{Niðurstöður}

Alls voru gerð 66 míturlokuskipti á 64 sjúklingum, par af 40 körlum (63\%). Tveir sjúklinganna gengust tvisvar undir míturlokuskipti á Landspítala og var enduraðgerðin gerð vegna vandamála sem tengdust lokunni, annars vegar hliðarleka (paravalvular leakage) og hins vegar sega á gerviloku. Tveir sjúklingar höfðu áður gengist undir míturlokuskipti í London og var einn peirra með leka meðfram loku og hinn með hjartapelsbólgu. Meðalaldur hópsins var 59 ár og var yngsti sjúklingurinn 17 ára og sá elsti 85 ára.

Fjöldi míturlokuskipta á tímabilinu 1990-2009, skipt upp í fimm ára tímabil, er sýndur á mynd 1. Til samanburðar er sýndur fjöldi míturlokuviðgerða, en pær voru samtals 113 á rannsóknartímabilinu. Á fyrsta fimm ára tímabilinu voru gerð 21 míturlokuskipti en 12 á pví síðasta.

Sjúklingatengdir pættir eru sýndir í töflu I. Tæplega helmingur sjúklinganna var of pungur og 62\% höfðu áður reykt. Alls voru 87\% sjúklinganna í NYHA-flokki III eða IV, 38 voru í ASA flokki IV og logEuroSCORE var að meðaltali 14,9\% (bil 1,5-88,4). Rúmlega helmingur sjúklinga hafði kransæðasjúkdóm, fjórðungur hafði áður gengist undir hjartaaðgerð og 10 sjúklingar höfðu virka sýkingu í míturlokunni (hjartapelsbólgu) pegar peir gengust undir aðgerð. Tíu aðgerðanna voru bráðaaðgerðir, í helmingi tilfella vegna hjartapelsbólgu og hjá premur vegna hjartadreps.
Tafla III. Niðurstöður hjartaómskoðana fyrir aðgerð. Gefin eru upp meðaltöl og staðalfrávik nema að annað sé tekið fram.

\begin{tabular}{lcc} 
& Leki $(\mathrm{n}=47)$ & Prengsli $(\mathrm{n}=18)$ \\
Útstreymisbrot vinstri slegils $(\%)$ & $53 \pm 16$ & $57 \pm 12$ \\
\hline Stærð vinstri gáttar $(\mathrm{mm})$ & $51 \pm 11$ & $52 \pm 10$ \\
\hline Stærð vinstri slegils í lok hlébils $(\mathrm{mm})$ & $61 \pm 10$ & $51 \pm 7$ \\
\hline Stærð vinstri slegils í lok slagbils $(\mathrm{mm})$ & $42 \pm 10$ & $35 \pm 8$ \\
\hline Meðalprýstingsfall yfir míturloku $(\mathrm{mmHg})$ & & $11 \pm 5$ \\
\hline Lokuflatarmál $\left(\mathrm{cm}^{2}\right)$ & & $1,2 \pm 0,4$ \\
\hline Lokuleki $(0-3)$ & $2,8 \pm 0,5$ & $1,4 \pm 0,8$ \\
\hline Hlutfall sjúklinga með lokuleka $>2 / 3(\%)$ & 88 & 9
\end{tabular}

Míturlokuleki var algengari en prengsli og höfðu 47 sjúklingar leka (71\%). Í töflu II eru ástæður míturlokuleka flokkaðar nánar. Algengasta orsök míturlokuleka var bakfall á míturlokublaði/ blöðum, eða hjá rúmlega priðjungi peirra sem höfðu leka. Par á eftir kom hjartapelsbólga (19\%) og aðgerð vegna endurleka eftir fyrri míturlokuviðgerð (11\%). Átján sjúklingar (27\%) höfðu prengsli, 12 fyrri tíu árin og 6 pau tíu síðari. Tæpur helmingur sjúklinga með prengsli hafði fengið gigtsótt. Einn sjúklingur hafði hvorki leka né prengsli í lokunni og var aðgerðin gerð vegna æxlis á fremra míturlokublaði sem reyndist slímvefjaræxli.

Í töflu III sjást niðurstöður úr hjartaómskoðun fyrir aðgerð, bæði fyrir sjúklinga með leka og prengsli í lokunni. Útstreymisbrot vinstri slegils hjá sjúklingum með lokuleka var að meðaltali $54 \%$. Stærð vinstri slegils í lok hlébils hjá sjúklingum sem fóru í aðgerð vegna lokuleka var að meðaltali $61 \mathrm{~mm}$ samanborið við 51 mm hjá peim sem höfðu prengsli. Meðalstærð vinstri gáttar hjá bæði sjúklingum með lokuprengsli og lokuleka var rúmlega 50 $\mathrm{mm}$.

Fjörutíu og prír sjúklingar (65\%) gengust undir aðra hjartaaðgerð samhliða míturlokuskiptum. Algengasta aðgerðin var kransæðahjáveita (41\%) og var miðgildi kransæðatenginga 2 (bil 1-4). par á eftir komu ósæðarlokuskipti (20\%), príblöðkulokuviðgerð (9\%) og MAZE-aðgerð vegna gáttatifs með frysti- eða brennslutækni (8\%).

Sex sjúklingar fengu lífræna loku ígrædda en hinir 60 gerviloku. Lokutegundir eru sýndar í töflu IV. Lokustærð var að meðaltali $30 \pm 1 \mathrm{~mm}$ og miðast við uppgefna stærð framleiðanda.

Aðgerðirnar tóku að meðaltali $295 \pm 125$ mínútur, par af voru $166 \pm 83$ mínútur á hjarta- og lungnavél og tangartími $115 \pm 69$ mínútur. Í fjórum aðgerðanna (6,9\%) varð meiriháttar blæðing (>5 L) í aðgerð. Blæðing fyrstu 24 klukkustundirnar eftir aðgerð

Tafla IV. Lokutegundir, fjöldi (\%).

\begin{tabular}{|c|c|}
\hline Gerviloka & $60(91)$ \\
\hline St Jude Medical ${ }^{\circledR}$ bileaflet & $27(41)$ \\
\hline Carbomedics ${ }^{\circledR}$ bileaflet & $33(50)$ \\
\hline Lífræn loka & $6(9)$ \\
\hline Carpentier Edwards $^{\circledR}$ Perimount Magna ${ }^{\mathrm{TM}}$ & $2(3)$ \\
\hline Carpentier Edwards ${ }^{\circledR}$ Porcine $^{\mathrm{TM}}$ & $1(2)$ \\
\hline St. Jude Medical ${ }^{\circledR}$ Epic $^{T M}$ & $3(5)$ \\
\hline
\end{tabular}


Tafla V. Snemmkomnir fylgikvillar. Sjúklingur getur haft fleiri en einn fylgikvilla. Fjöldi (\%).

\begin{tabular}{|c|c|}
\hline Alvarlegir fylgikvillar & $31(47)$ \\
\hline Hjartadrep tengt aðgerð* & $15(26)$ \\
\hline Alvarleg öndunarbilun & $11(17)^{\dagger}$ \\
\hline Enduraðgerð vegna blæðingar & $10(15)$ \\
\hline $\begin{array}{l}\text { Hjartabilun í tengslum við aðgerð sem krafðist ósæðardælu } \\
(n=6) \text { eða ECMO dælu }(n=3)\end{array}$ & $9(14)$ \\
\hline Bráð nýrnabilun sem leiddi til skilunar & $6(9)$ \\
\hline Varanlegt heiladrep & $2(3)$ \\
\hline Enduraðgerð vegna hliðarlokuleka & $1(2)$ \\
\hline Sýking/los í bringubeini & $2(3)$ \\
\hline Hjartapelsbólga & $1(2)$ \\
\hline Minniháttar fylgikvillar & $40(61)$ \\
\hline Nýtilkomið gáttatif/-flökt ${ }^{\ddagger}$ & $17(45)$ \\
\hline Minniháttar hjartaskađis & $18(31)$ \\
\hline Fleiðruvökvi sem krafðist aftöppunar & $17(26)$ \\
\hline Lungnabólga & $8(12)$ \\
\hline Bráđur nýrnaskaði" sem ekki parfnaðist blóðskilunar & $5(8)$ \\
\hline Gollurshúsvökvi sem krafðist aftöppunar & $5(8)$ \\
\hline Pvagfærasýking & $3(6)$ \\
\hline Hægataktur sem krafðist gangráðsísetningar & $2(3)$ \\
\hline Yfirborðssýking í skurðsári & $2(3)$ \\
\hline
\end{tabular}

* ST-hækkanir á hjartariti eđa CK-MB mæling yfir 100 g/L hjá sjúklingum sem ekki höfðu hjartadrep fyrir aðgerð.

† Meðferð í öndunarvél lengur en í eina viku. Sex pessara sjúklinga fengu barkaraufun.

† Meðferð i öndunarvél lengur en i eina viku. Sex pessara sjúklinga fengu bark

§ CK-MB-mæling 70-100 $\mu \mathrm{g} / \mathrm{L}$ eftir aðgerð hjá sjúklingum sem ekki höfðu hjartadrep

fyrir aðgerð.

ๆ Kreatínín >200 mol/L hjá sjúklingum sem ekki höfðu hækkað kreatínín fyrir aðgerô.

var að meðaltali $1166 \pm 1079 \mathrm{~mL}$. Miðgildi fjölda gefinna eininga af rauðkornapykkni eftir aðgerð var 7 (bil 0-87, meðaltal 12,3), en blóðvökva 5 (bil 0-63, meðaltal 13,3) og blóðflaga 0 (bil 0-25, meðaltal 2,6). Miðgildi tíma í öndunarvél eftir aðgerðina var 17 tímar, eða frá premur og upp í 1700 klukkutímar (10 vikur). Miðgildi gjörgæslulegu voru 68 tímar (bil 12-1839) en heildarlegutími á sjúkrahúsi 24 dagar (bil 1-160).

Fylgikvillar eftir aðgerð eru sýndir í töflu V. Alvarlegir fylgikvillar greindust hjá rúmlega helmingi sjúklinga, en algengastir voru hjartadrep (30\%), alvarleg öndunarbilun $(17 \%)$ og enduraðgerð vegna blæðingar (15\%). Sex sjúklingar (9\%) purftu nýrnaskilun vegna bráðs nýrnaskaða og tveir hlutu varanlegt heiladrep. Sex sjúklingar purftu ósæðardælu (intra-aortic balloon pump, IABP) eftir aðgerð vegna hjartabilunar og prír meðferð með ECMO (extra corporeal membraneous oxygenation) á gjörgæsludeild. Minniháttar fylgikvillar greindust hjá 40 (61\%) sjúklingum og voru algengustu fylgikvillarnir fleiðruvökvi sem parfnaðist aftöppunar, nýtilkomið gáttatif og lungnabólga. Sex sjúklingar létust innan 30 daga og var skurðdauði pví 9\%. Í töflu VI eru nánari upplýsingar um pessa sex sjúklinga, meðal annars dánarorsakir peirra. Prír sjúklingar til viðbótar létust fyrir útskrift og var sjúkrahúsdauði (hospital mortality) pví 14\%.

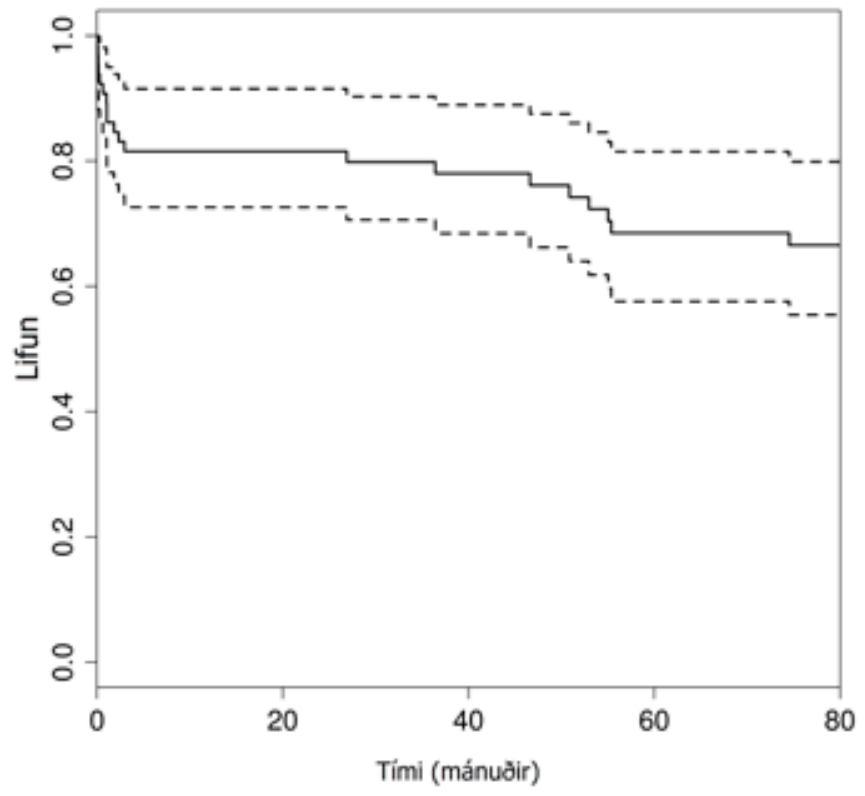

Mynd 2. Heildarlifun (Kaplan-Meier) sjúklinga (svört lína) með 95\% vikmörkum (brotnar linur).

Heildarlifun sjúklinganna eftir míturlokuskipti er sýnd á mynd 2. Fimm ára lifun var $69 \%$ (95\% ÖB: 58-82). Fjölbreytugreining á forspárbáttum lifunar leiddi í ljós að hærri aldur (ÁH 1,03; 95\% ÖB 1,00-1,08; p=0,047) reyndist neikvæður forspárpáttur lifunar. Hins vegar reyndust kyn, logEuroSCORE og NYHA-flokkur, auk tilkomu annarrar samhliða aðgerðar eins og ósæðarlokuskipta og tangartími, ekki hafa áhrif á langtímalifun. Ef NYHA-flokkun var sleppt voru bæði aldur (ÁH 1,04; 95\% ÖB 1,00-1,07; p=0,047) og hærra logEuroSCORE (ÁH 1,02; 95\% ÖB 1,00-1,04; p=0,019) sjálfstæðir marktækir áhættupættir. Líkanið var prófað með NYHAflokkun en án logEuroSCORE, og styrkti pað áhrif aldurs (ÁH 1,05, ÖB 1,01-1,09, p=0,008), en aðrar breytur höfðu ekki marktæk tengsl við langtímalifun.

\section{Umræða}

Helstu markmið pessarar rannsóknar voru að meta árangur míturlokuskipta hér á landi með áherslu á skammtímafylgikvilla, dánarhlutfall innan 30 daga og langtímalifun. Fylgikvillar reyndust algengir og alvarlegir fylgikvillar greindust hjá tæpum helmingi sjúklinga. Petta verður að teljast hátt hlutfall og er nokkru hærra en bæði við ósæðarlokuskipti (33\%) $)^{15}$ og kransæðahjáveituaðgerðir $(9,6 \%)$ hér á landi. ${ }^{16}$ Af peim sem ekki höfðu hjartadrep fyrir aðgerð fengu $25 \%$ hjartadrep í tengslum við aðgerðina. Petta er næstum helmingi hærra en í áðurnefndri rannsókn á ósæðarlokuskiptum og sennilega má helst rekja pað til langs tangartíma í pessum aðgerðum. Margir pessara sjúklinga áttu við alvarlega öndunarbilun að stríða og purftu að vera lengur en eina viku í öndunarvél. Í afturskyggnri rannsókn getur verið erfitt að greina nákvæma ástæðu öndunarbilunar í hverju tilfelli en oftast var um brátt andnauðarheilkenni (adult respiratory distress syndrome, ARDS) og hjartabilun að ræða. Enduraðgerðir vegna blæðingar voru álíka algengar eftir míturlokuskipti (15\%) og ósæðarlokuskipti (17\%), en í nýlegri rannsókn af Landspítala var tíðni enduraðgerða vegna blæðingar 8\% eftir allar opnar hjartaaðgerðir. ${ }^{17}$ Pessi munur kann 
Tafla VI. Yfirlit yfir sjúklinga sem létust innan 30 daga.

\begin{tabular}{|c|c|c|c|c|c|c|c|c|c|c|c|c|}
\hline Nr. & $\begin{array}{l}\text { Aldur/ } \\
\text { kyn }\end{array}$ & $\begin{array}{l}\text { NYHA flokkur }{ }^{\star} / \\
\text { logEuroSCORE }\end{array}$ & Greining & $\begin{array}{l}\text { Lífræn } \\
\text { loka }\end{array}$ & $\begin{array}{c}\text { Önnur } \\
\text { samhliða } \\
\text { hjartaaðgerð }\end{array}$ & $\begin{array}{l}\text { Fyrst } \\
\text { reynd } \\
\text { viơgerð }\end{array}$ & $\begin{array}{l}\text { Tangar- } \\
\text { tími } \\
\text { (mín) }\end{array}$ & $\begin{array}{l}\text { Ósæðar- } \\
\text { dæla/ } \\
\text { ECMO } \\
\text { dæla† }\end{array}$ & $\begin{array}{l}\text { Blóð- } \\
\text { gjöfł }\end{array}$ & $\begin{array}{l}\text { Endur- } \\
\text { aðgerð } \\
\text { vegna } \\
\text { blæðingar }\end{array}$ & $\begin{array}{l}\text { Lifun } \\
\text { (dagar) }\end{array}$ & Dánarorsök \\
\hline 1 & $74 / \mathrm{kk}$ & IV / 74,5 & $\begin{array}{l}\text { Enduraðgerð } \\
\text { vegna leka í } \\
\text { míturlokuviðgerð } \\
\text { sama dag }\end{array}$ & + & - & - & 162 & $-1-$ & 5 & - & 3 & $\begin{array}{c}\text { Hjartadrep í } \\
\text { tengslum við } \\
\text { aðgerð }\end{array}$ \\
\hline 2 & $47 / \mathrm{kk}$ & IV /88,4 & $\begin{array}{c}\text { Leki vegna } \\
\text { hjartapelsbólgu }\end{array}$ & - & - & - & 120 & $-/-$ & 37 & + & 19 & Sýklasótt \\
\hline 3 & $71 / \mathrm{kk}$ & IV /31,1 & $\begin{array}{l}\text { Hjartadrep með } \\
\text { rofi á totuvöðva }\end{array}$ & - & $\begin{array}{l}\text { Kransæða- } \\
\text { hjáveita }\end{array}$ & - & 311 & $-/+$ & 23 & - & 4 & $\begin{array}{l}\text { Hjartadrep, } \\
\text { andnauðar- } \\
\text { heilkenni }\end{array}$ \\
\hline 4 & $60 / \mathrm{kk}$ & III /20,2 & $\begin{array}{c}\text { Leki vegna } \\
\text { hjartapelsbólgu }\end{array}$ & - & - & + & 285 & $+/+$ & 87 & - & 9 & Fjöllíffærabilun \\
\hline 5 & $65 / k v k$ & III / 11,0 & $\begin{array}{l}\text { Leki vegna } \\
\text { blóðpurrðar í hjarta }\end{array}$ & - & $\begin{array}{l}\text { Kransæða- } \\
\text { hjáveita }\end{array}$ & + & 355 & $+/-$ & 15 & - & 1 & $\begin{array}{l}\text { Hjartadrep í } \\
\text { tengslum við } \\
\text { aðgerð }\end{array}$ \\
\hline 6 & $50 / \mathrm{kk}$ & III /5,5 & $\begin{array}{l}\text { Leki vegna aftara } \\
\text { míturlokubakfalls }\end{array}$ & + & $\begin{array}{l}\text { Ósæðarloku- } \\
\text { skipti }\end{array}$ & - & 222 & $-1+$ & 38 & + & 5 & $\begin{array}{c}\text { Fjöllíffærabilun, } \\
\text { hjartadrep í } \\
\text { tengslum við } \\
\text { aðgerð }\end{array}$ \\
\hline
\end{tabular}

* fyrir aðgerð † eftir aðgerð $\ddagger$ fjöldi eininga rauðkornapykknis

að skýrast af pví að míturlokuskipti eru tæknilega flóknar aðgerðir og krefjast lengri tíma á hjarta- og lungnavél, sem eykur hættu á blæðingum..$^{18}$ Hins vegar var tíðni sýkinga í bringubeini og heiladreps í tengslum við aðgerð lág í pessari rannsókn. Minniháttar fylgikvillar greindust hjá rúmlega helmingi sjúklinga. Nýtilkomið gáttatif eða flökt var algengast, eða hjá $45 \%$ sjúklinga, en pá eru ekki taldir með peir 28 sjúklingar sem höfðu pekkt gáttatif fyrir aðgerðina. Tíðni nýtilkomins gáttatifs reyndist umtalsvert lægra en eftir ósæðarlokuskipti vegna ósæðarprengsla, en par var pað $76 \% \cdot{ }^{15}$ Ekki er ljóst hvað skýrir pennan mun, en tæknilega flóknum aðgerðum eins og míturlokuaðgerðum fylgir oft há tíðni gáttatifs. ${ }^{12}$ Á móti kemur að sjúklingar í pessari rannsókn voru að meðaltali 13 árum yngri en peir sem gengustu undir ósæðarlokuskipti, en tíðni gáttatifs eykst með aldri. ${ }^{15}$ Pessi rannsókn tók til 20 ára tímabils og er hugsanlegt að gáttatif hafi verið vangreint á fyrri hluta rannsóknartímabilsins pegar eftirfylgd sjúklinga með hjartarafsjá var styttri en í ósæðarlokurannsókninni sem tók til áranna 2002-2006.

Hlutfall sjúklinga sem létust innan 30 daga reyndist $9 \%$, sem er svipað eða lægra en í erlendum rannsóknum. ${ }^{19-22}$ Beinn samanburður er pó erfiður par sem sumar erlendu rannsóknanna tóku ekki með ákveðna sjúklingahópa, til dæmis sjúklinga sem gengust undir bráðaaðgerðir og endurtekin míturlokuskipti. 19, 20, 22 Par sem bráðaaðgerðir voru einnig teknar með í pessari rannsókn hefði allt eins mátt búast við enn hærra dánarhlutfalli, en dánarhlutfall án bráðaaðgerða var aðeins 5\%. Í nýlegri sænskri rannsókn með svipuðu sjúklingapýði reyndist dánarhlutfall innan 30 daga $9,7 \% .22$

Dánarhlutfall eftir míturlokuskipti reyndist hærra en eftir ósæðarlokuskipti á Íslandi par sem pað var 6,4\%. ${ }^{15}$ Petta er í samræmi við erlendar rannsóknir ${ }^{23}$ og kann að skýrast af mismunandi eðli aðgerðanna og að í pessari rannsókn höfðu margir sjúklingar brátt hjartadrep og hjartapelsbólgu. Petta endurspeglast meðal annars í háu logEuroSCORE (14,9\%) en einnig peirri staðreynd að 87\% sjúklinga voru í NYHA-flokki III eða IV, og pví með veruleg einkenni hjartabilunar fyrir aðgerð. Par að auki hafði fjórðungur sjúklinga áður gengist undir hjartaaðgerð en í erlendum rannsóknum er dánarhlutfall innan 30 daga oft mun hærra eftir enduraðgerðir á míturloku, enda pótt lægra hlutfalli (8\%) hafi verið lýst. ${ }^{24}$

Útstreymisbrot vinstri slegils var að meðaltali lækkað og slegillinn stækkaður hjá sjúklingum með míturlokuleka. Útstreymisbrot er yfirleitt ofmetið í míturlokuleka par sem stór hluti slagrúmmáls er dælt til baka í vinstri gátt. Pannig getur útstreymisbrot verið eðlilegt hjá slíkum sjúklingum pótt samdráttargeta vinstri slegils sé skert. ${ }^{25}$ Athyglisvert er að hjá flestum sjúklingum með leka var útstreymisbrot vinstri slegils undir $60 \%$, en yfirleitt er mælt með aðgerð við lokuleka áður en starfsemi vinstri slegils skerðist. ${ }^{2,} 8$ Par sem stór hluti sjúklinganna var með skerta starfsemi vinstri slegils og einkenni hjartabilunar fyrir aðgerð virðast peir hafa komið seint til aðgerðar, án pess að ástæða pess sé pekkt. Aðrir sjúklingar höfðu sögu um brátt hjartadrep eða leka vegna langvinns blóðpurrðarsjúkdóms, sem gæti skýrt skerta starfsemi vinstra slegils og hjartabilun.

Míturlokuskiptum hefur fækkað verulega frá pví fyrsta aðgerðin var gerð hér á landi fyrir rúmum tveimur áratugum. Pannig voru næstum helmingi fleiri aðgerðir gerðar fyrstu 5 ár rannsóknarinnar, en síðustu 5 árin aðeins tvær aðgerðir að meðaltali á ári. Hlutfall míturlokuskiptaaðgerða af öllum hjartaaðgerðum sem framkvæmdar eru hér á landi er enn lægra, pví hjartaaðgerðum hefur fjölgað á peim 20 árum sem rannsóknin tók til.

Gigtsótt er talin orsök langflestra tilfella míturlokuprengsla, enda pótt saga um gigtsótt fáist ekki nema í helmingi tilfella, ${ }^{1}$ eins og sást í pessari rannsókn. Fækkun míturlokuskipta hér á landi tengist að einhverju leyti fækkun tilfella af míturlokuprengslum sem líklega má rekja til lægri tíðni gigtsóttar hérlendis. Vaxandi fjöldi míturlokuviðgerða hjá sjúklingum með lokuleka hefur pó sennilega meira að segja. Eins og sést á mynd 1 pá jókst hlutfall viðgerða úr 34\% árin 1990-1994 í 81\% árin 2005-2009 og undir lok rannsóknartímabilsins voru viðgerðir rúmlega fjórum sinnum algengari en míturlokuskipti. Svipuð próun hefur sést á stærri 
hjartaskurðdeildum erlendis par sem hlutfall viðgerða við míturlokuleka er komið yfir 75\%. ${ }^{26}$ Hátt hlutfall viðgerða hérlendis verður að teljast jákvætt, enda sýna rannsóknir að snemmkominn árangur og langtímalifun er mun betri eftir viðgerð en lokuskipti. ${ }^{27}$ Með aukinni próun míturlokuviðgerða, meðal annars með hjartapræðingartækni, er sennilegt að hlutfall pessara viðgerða komi til með að hækka enn frekar.

Gervilokur voru notaðar hjá 91\% sjúklinga en sex peirra fengu lífræna loku. Petta er öfugt við ósæðarlokuskipti en par fengu 81\% sjúklinganna lífræna loku. ${ }^{15}$ Skýringin á pessum mun er aðallega sú að meðalaldur sjúklinganna í pessari rannsókn var umtalsvert lægri, en oftast er mælt með gerviloku hjá sjúklingum undir 65-70 ára aldri. ${ }^{12}$ Athyglisvert er að næstum tveir priðju sjúklinga gengust samtímis undir aðrar aðgerðir. Pannig fengu 20\% sjúklinga bæði ósæðar- og míturloku í sömu aðgerð og 40\% gengust einnig undir kransæðahjáveitu. Slík inngrip lengja tíma á hjartaog lungnavél og tangartíma sem aftur eykur tíðni fylgikvilla í og eftir aðgerð. Petta endurspeglast í langri dvöl á gjörgæslu og sjúkrahúsi.

Fimm ára lifun í pessari rannsókn var 69\% sem er í samræmi við niðurstöður erlendra rannsókna sem flestar sýna lifun á bilinu 65 til 85\%.19,22, 28, 29 Til samanburðar var 5 ára lifun hér á landi eftir lokuskipti vegna ósæðarlokuprengsla $78 \%{ }^{30}$
Styrkleiki pessarar rannsóknar er að hún nær til heillar pjóðar par sem sjúklingarnir voru allir meðhöndlaðir á sömu stofnun. Takmarkandi páttur er að rannsóknin er afturskyggn og nær langt aftur í tímann. Á pessum tveimur áratugum hafa orðið miklar framfarir í hjartaskurðlækningum og gjörgæslumeðferð sem gerir samanburð á árangri við aðrar rannsóknir og milli tímabila erfiðan. Heildrænni mynd af skurðmeðferð míturlokusjúkdóms mun fást pegar rannsókn sem er í gangi á árangri míturlokuviðgerða lýkur.

Niðurstaða pessarar rannsóknar er að tíðni fylgikvilla er há eftir míturlokuskipti, enda margir sjúklinganna með alvarlegan hjartasjúkdóm fyrir aðgerð. Skurðdauði er pó lægri hér á landi en í mörgum sambærilegum erlendum rannsóknum og langtímalifun í hærra lagi. Míturlokuskiptaaðgerðum hefur fækkað á Íslandi undanfarin ár samfara hærri tíðni míturlokuviðgerða.

\section{Pakkir}

Gunnhildi Jóhannsdóttur skrifstofustjóra eru færðar pakkir fyrir aðstoð við öflun sjúkraskráa. Rannsóknin var styrkt af Vísindasjóði Landspítala, Rannsóknarsjóði Háskóla Íslands og Minningarsjóði Bents Scheving Thorsteinssonar.

\section{Heimildir}

1. Chandrashekhar Y, Westaby S, Narula J. Mitral stenosis. Lancet 2009; 374: 1271-83.

2. Enriquez-Sarano $\mathrm{M}$, Akins CW, Vahanian A. Mitral regurgitation. Lancet 2009; 373: 1382-94.

3. Seckeler MD, Hoke TR. The worldwide epidemiology of acute rheumatic fever and rheumatic heart disease. Clin Epidemiol 2011; 3: 67-84.

4. Sigurionsson $\mathrm{H}$, Andersen $\mathrm{K}$, Gardarsdottir $\mathrm{M}$, Petursdottir V, Klemenzson G, Gunnarsson G, et al. Cardiac myxoma in Iceland: a case series with an estimation of population incidence. APMIS 2011; 119: 611-7.

5. Arora R, Kalra GS, Murty GS, Trehan V, Jolly N, Mohan JC, et al. Percutaneous transatrial mitral commissurotomy: immediate and intermediate results. J Am Coll Cardiol 1994; 23: 1327-32.

6. Iung B, Vahanian A. Epidemiology of valvular heart disease in the adult. Nat Rev Cardiol 2011; 8: 162-72.

7. Goldberg SL, Feldman T. Percutaneous mitral valve interventions: overview of new approaches. Curr Cardio Rep 2010; 12: 404-12.

8. Bonow RO, Carabello BA, Chatterjee $\mathrm{K}$, de Leon AC Jr., Faxon DP, Freed MD, et al. 2008 focused update incorporated into the ACC/AHA 2006 guidelines for the management of patients with valvular heart disease: report of the American College of Cardiology/American Heart Association Task Force on Practice Guidelines (Writing Committee to revise the 1998 guidelines for the management of patients with valvular heart disease). Endorsed by the Society of Cardiovascular Anesthesiologists, Society for Cardiovascular Angiography and Interventions, and Society of Thoracic Surgeons. J Am Coll Cardiol 2008; 52: e1-142.

9. Adams DH, Rosenhek R, Falk V. Degenerative mitra valve regurgitation: best practice revolution. Eur Heart 2010; 31: 1958-66.

10. Lee EM, Shapiro LM, Wells FC. Importance of subvalvular preservation and early operation in mitral valve surgery. Circulation 1996; 94: 2117-23.

11. Cobanoglu A, Grunkemeier GL, Aru GM, McKinley CL, Starr A. Mitral replacement: clinical experience with a ball-valve prosthesis. Twenty-five years later. Ann Surg 1985; 202: 376-83.
12. Vahanian A, Baumgartner H, Bax J, Butchart E, Dion R, Filippatos G, et al. Guidelines on the management of valvular heart disease: The Task Force on the Management of Valvular Heart Disease of the European Society of Cardiology. Eur Heart J 2007; 28: 230-68.

13. Baumgartner $\mathrm{H}$, Hung J, Bermejo J, Chambers JB, Evangelista A, Griffin BP, et al. Echocardiographic assessment of valve stenosis: EAE/ASE recommendations for clinical practice. Eur J Echocardiogr 2009; 10: 1-25.

14. Cheitlin MD, Armstrong WF, Aurigemma GP, Beller GA, Bierman FZ, Davis JL, et al. ACC/AHA/ASE 2003 Guideline Update for the Clinical Application of Echocardiography: summary article. A report of the American College of Cardiology/American Heart Association Task Force on Practice Guidelines (ACC) AHA/ASE Committee to Update the 1997 Guidelines for the Clinical Application of Echocardiography). J Am Soc Echocardiogr 2003; 16: 1091-110.

15. Ingvarsdottir IL, Viktorsson SA, Hreinsson K, Sigurdsson MI, Helgadottir S, Arnorsson P, et al. Lokuskipti vegna ósæðarlokuprengsla á Î́landi 2002-2006: Ábendingar og snemmkomnir fylgikvillar. Læknablaðið 2011; 97: 523-7.

16. Oddsson SJ, Sigurjonsson H, Helgadottir S, Sigurdsson MI, Viktorsson SA, Arnorsson T, et al. Tengsl offitu við árangur kransæðahjáveituaðgerða. Læknablaðið 2011; 97 223-8.

17. Smárason NV, Sigurjónsson H, Hreinsson K, Arnórsson T, Gudbjartsson T. Enduraðgerðir vegna blæðinga eftir opnar hjartaskurðaðgerðir. Læknablaðið 2009; 95: 567-73.

18. Paparella D, Brister SJ, Buchanan MR. Coagulation disorders of cardiopulmonary bypass: a review. Intensive Care Med 2004; 30: 1873-81

19. Fiore AC, Barner HB, Swartz MT, McBride LR, Labovitz $\mathrm{AJ}$, Vaca $\mathrm{KJ}$, et al. Mitral valve replacement: randomized trial of St. Jude and Medtronic Hall prostheses. Ann Thorac Surg 1998; 66: 707-12.

20. Cohn LH, Allred EN, Cohn LA, Austin JC, Sabik J, DiSesa VJ, et al. Early and late risk of mitral valve replacement. A 12 year concomitant comparison of the porcine bioprosthetic and prosthetic disc mitral valves. J Thorac Cardiovasc Surg 1985; 90: 872-81.
21. Borger MA, Yau TM, Rao V, Scully HE, David TE. Reoperative mitral valve replacement: importance of preservation of the subvalvular apparatus. Ann Thorac Surg 2002; 74: 1482-7.

22. Hellgren L, Kvidal P, Horte LG, Krusemo UB, Stahle E. Survival after mitral valve replacement: rationale for surgery before occurrence of severe symptoms. Ann Thor Surg 2004; 78: 1241-7.

23. Edwards FH, Peterson ED, Coombs LP, DeLong ER, Jamieson WR, Shroyer ALW, et al. Prediction of operative mortality after valve replacement surgery. J Am Coll Cardiol 2001; 37: 885-92

24. Emery RW, Krogh CC, McAdams S, Emery AM, Holter AR. Long-term follow up of patients undergoing reoperative surgery with aortic or mitral valve replacement using a St. Jude Medical prosthesis. J Heart Valve Dis 2010; 19: 473-84.

25. Starling MR, Kirsh MM, Montgomery DG, Gross MD. Impaired left ventricular contractile function in patients with long-term mitral regurgitation and normal ejection fraction. J Am Coll Cardiol 1993; 22: 239-50.

26. Gammie JS, O'Brien SM, Griffith BP, Ferguson TB, Peterson ED. Influence of hospital procedural volume on care process and mortality for patients undergoing elective surgery for mitral regurgitation. Circulation 2007; 115: 881-7.

27. Mohty D, Orszulak TA, Schaff HV, Avierinos JE, Tajik JA, Enriquez-Sarano M. Very long-term survival and durability of mitral valve repair for mitral valve prolapse. Circulation 2001; 104 (12 Suppl 1): I1-I7.

28. Masters RG, Helou J, Pipe AL, Keon WJ. Comparative clinical outcomes with St. Jude Medical, Medtronic Hall and CarboMedics mechanical heart valves. J Heart Valve Dis 2001; 10: 403-9.

29. Aupart MR, Neville PH, Hammami S, Sirinelli AL, Meurisse YA, Marchand MA. Carpentier-Edwards pericardial valves in the mitral position: ten-year follow-up. J Thorac Cardiovasc Surg 1997; 113: 492-8.

30. Viktorsson SA, Ingvarsdottir IL, Hreinsson K, Sigurdsson MI, Helgadottir S, Arnorsson P, et al. Lokuskipti vegna ósæðarlokuprengsla á Íslandi 2002-2006: Langtímafylgikvillar og lifun. Læknablaðið 2011; 97: 591-5. 


\section{ENGLISH SUMMARY}

\section{Outcome of mitral valve replacement in Iceland}

Ragnarsson S1, Sigurdsson MI', Danielsen $\mathrm{R}^{2,3}$, Arnorsson $\mathrm{T}^{1}$, Gudbjartsson $\mathrm{T}^{1,3}$

Introduction: Mitral valve replacement (MVR) is the second most common valvular replacement procedure after aortic valve replacement (AVR). Studies on the outcome of MVR in Iceland have been missing. We therefore studied short and long-term results following MVR in Iceland, Material and methods: A retrospective nationwide study on 64 patients (mean age 59 years, 63\% males) that underwent 66 MVR procedures in Iceland between 1990-2010. Clinical data was retrieved from patient charts and overall survival estimated. The mean follow-up was 7.4 years. Results: Mitral regurgitation or stenosis was the indication for MVR in $71 \%$ and $27 \%$ of cases, respectively. Nine patients had endocarditis and 8 a recent myocardial infarction. The mean logEuroSCORE was $14.9 \%$ (range $1.5-88.4$ ), $83 \%$ of the patients were in NYHA class III/IV preoperatively and $24 \%$ had previously undergone cardiac surgery. A biological valve was implanted in six cases and a mechanical valve used in 60 cases. Concomitant CABG was performed in $41 \%$ of patients and AVR in $20 \%$. Perioperative myocardial infarction (26\%), acute respiratory failure (17\%), reoperation for bleeding $(15 \%)$ and acute renal failure requiring dialysis $(9 \%)$ were the most common major complications. Three patients required extracorporeal membrane oxygenation (ECMO) and six patients an intra-aortic balloon pump (IABP) postoperatively. Minor complications were noted in $61 \%$ of cases. Six patients died within 30 days (9\%) and five year survival was $69 \%$.

Conclusion: The frequency of complication following MVR was high and represents the severity of the underlying heart disease. The operative mortality in the current study was in the lower range compared to other studies.

Correspondence: Tómas Guðbjartsson, tomasgud@landspitali.is

Key words: Mitral valve replacement (MVR), mitral valve stenosis, mitral valve regurgitation, complications, outcome, survival.

Departments of ${ }^{1}$ Cardiothoracic surgery and ${ }^{2}$ Cardiology, Landspitali University Hospital, ${ }^{3}$ Faculty of Medicine, University of Iceland.

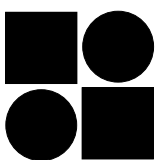

\section{Vísinda- og próunarstyrkir}

\section{Vorúthlutun 2012}

Vísindasjóður Félags íslenskra heimilislækna $(\mathrm{FíH})$ úthlutar styrkjum til vísinda- og próunarverkefna á sviði heilsugæslu tvisvar á ári.

Sjóðurinn veitir einnig sérstaka starfsstyrki til slíkrar vinnu.

Umsóknir um vorúthlutun 2012 purfa að berast sjóðnum fyrir 23. apríl næstkomandi og ber að skila rafrænt til Margrétar Aðalsteinsdóttur magga@lis.is hjá Læknafélagi Íslands, Hlíðasmára 8, 201 Kópavogi, ásamt rannsóknar- og fjárhagsáætlunum eða framgangsskýrslu ef um endurumsókn sama verkefnis er að ræða. Umsóknareyðublað̃ má nálgast á innri vef lis.is

Starfsstyrkir geta verið allt frá einum til 12 mánaða í senn. Upphæð starfsstyrks miðast við fasta upphæð sem svarar til dagvinnulauna styrkpega og er pá tekið mið af menntun og starfsaldri, pó aldrei hærri en sem svarar dagvinnulaunum yfirlæknis í heilsugæslu. Sé styrkpegi starfandi á heilbrigðisstofnun innan heilsugæslunnar leggur stjórn Vísindasjóðsins til að styrkurinn verði greiddur beint til peirrar stofnunar. Á móti komi að forsvarsmenn stofnunarinnar sjái til pess að styrkpegi haldi áfram starfi sínu, óbreyttum launum og réttindum, en fái jafnframt tíma til að sinna rannsóknarstörfum á dagvinnutíma.

Við mat á umsóknum er lögð áhersla á að rannsóknarverkefnið sé á forsendum heilsugæslunnar. Við vísindaverkefni er einnig lögð áhersla á tengs। rannsakenda við heimilislæknisfræði Háskóla Íslands eða aðra akademíska háskólastofnun í heimilislækningum.

Nánari upplýsingar veitir Jóhann Ágúst Sigurðsson johsig@hi.is

Stjórn Vísindasjóðs FíH 